\title{
Distribusi Arah Vertikal Butiran Hujan dari Hujan Stratiform di Kototabang dari Pengamatan Micro Rain Radar (MRR)
}

\author{
Ravidho Ramadhan, Marzuki* \\ Jurusan Fisika Universitas Andalas \\ *marzuki@sci.unand.ac.id
}

\begin{abstract}
ABSTRAK
Distribusi ukuran butiran hujan atau raindrop size distribution (RSD) arah vertikal hujan stratiform dari ketinggian 0,45 km hingga 4,65 km di atas permukaan tanah di Kototabang, Sumatera Barat $\left(0,20^{\circ} \mathrm{LS}\right.$; 100,32 BT; $865 \mathrm{~m}$ di atas permukaan laut ), telah diteliti melalui pengamatan Micro Rain Radar (MRR) selama Januari 2012 sampai Agustus 2016. RSD dari MRR dimodelkan dengan distribusi gamma dan parameternya didapatkan menggunakan metode momen. Pertumbuhan RSD dari hujan stratiform pada ketinggian 3,9-3,4 km sangat kuat untuk semua ukuran butiran, yang menandakan daerah melting layer di Kototabang. Di bawah daerah melting layer terjadi penurunan konsentrasi butiran berukuran kecil dan peningkatan konsentrasi butiran besar. Hal ini diperkirakan disebabkan oleh proses evaporasi dan updraft pada butiran kecil dan coalescence yang teramati pada hujan stratiform dengan intensitas tinggi. Hal ini juga ditandai dengan perubahan parameter gamma dan koefisien persamaan $Z-R\left(Z=A R^{b}\right)$ terhadap penurunan ketinggian. Dengan demikian, asumsi persamaan Z-R yang konstan untuk setiap ketinggian bagi hujan stratiform pada radar meteorologi khususnya di Kototabang kurang akurat. Kata kunci: Hujan stratiform, Kototabang, Micro Rain Radar (MRR), raindrop size distribution (RSD)
\end{abstract}

\section{ABSTRACT}

Vertical structure of raindrops size distribution (RSD) from 0.45-4.65 $\mathrm{km}$ above ground level for stratiform rain at Kototabang west Sumatra $\left(0,20^{\circ} \mathrm{S} ; 100,32^{\circ} \mathrm{E} ; 865 \mathrm{~m}\right.$ above sea level) has been investigated using Micro Rain Radar (MRR) observation during January 2012 - August 2016. The RSD was parameterized by modified gamma distribution and its parameter was calculated by a moment method. It was found that the growth of RSD from altitude of $3.9 \mathrm{~km}$ to $3.4 \mathrm{~km}$ was significantly observed for all raindrop sizes, which indicates melting layer height at Kototabang. Below the melting layer, there is a significant decrease and increase of small and large-sized drops, respectively, with decreasing height. Depletion of small-sized drops can be possibly due to evaporation process and updraft. Furthermore, coalescence process can increase the number of large-sized drops during stratiform rain with high intensity. These processes can be also inferred from the change of gamma RSD parameters and $Z-R$ relationship coefficients $\left(Z=A R^{b}\right)$ with decreasing height. Thus, the usage of constant $Z-R$ equation in Stratiform rain column may be less accurate to convert weather radar data in tropical regions particularly in West Sumatra.

Keywords: Kototabang, Micro Rain Radar (MRR), raindrops size distribution (RSD), stratiform rain

\section{PENDAHULUAN}

Studi tentang raindrops size distribution (RSD) memiliki berbagai aplikasi. RSD penting untuk mengestimasi atenuasi gelombang mikro dalam bidang telekomunikasi (Marzuki dkk., 2009). Selain itu, RSD juga berguna untuk mengetahui proses mikrofisika dalam pembentukan hujan (Tokay dan Short, 1996). Selanjutnya, RSD juga penting dalam perancangan sistem radar dan satelit meteorologi (Coppens dan Haddad, 2000) seperti perancangan remote sensing dalam pengamatan atmosfer dan pengamatan hujan.

Mengingat pentingnya RSD telah banyak penelitian yang dilakukan, salah satunya adalah penelitian tentang struktur vertikal dari RSD. Struktur vertikal RSD dapat menjelaskan proses pembentukan hujan (Tokay dan Short, 1996). Struktur vertikal RSD dapat diamati menggunakan radar, videosonde, dan precipitation occcurrance system. Radar sudah sangat umum digunakan dalam pengukuran distribusi vertikal RSD dan biasa disebut sebagai vertical pointing radar (VPR). VPR mengamati struktur vertikal RSD dengan cukup akurat dengan resolusi pengamatan yang baik (Chen dkk., 2016). VPR yang digunakan dalam pengamatan struktur vertikal RSD dapat berupa gelombang pulsa atau gelombang kontinyu. VPR dengan gelombang pulsa dalam pengamatan struktur vertikal RSD adalah kombinasi radar dengan ultra high frequency (UHF) dan very high frequency (VHF) (Currier dkk.,1992; Cifelli dkk., 2000; Vonnisa dkk., 2014). Radar UHF bekerja pada frekuensi sekitar 915 MHz sedangkan radar VHF 
bekerja pada frekuensi $50 \mathrm{MHz}$. VPR dengan gelombang pulsa ini memiliki kelemahan yaitu tidak semua ketinggian dapat teramati, terutama ketinggian yang dekat dengan permukaan tanah. Hal ini disebabkan adanya jarak minimal antara radar dan target agar tidak terjadi ambiguitas sinyal. Untuk mengatasi kelemahan tersebut telah dikembangkan radar yang menggunakan gelombang kontinyu seperti micro rain radar (MRR) (Peters dkk., 2002).

MRR merupakan radar dengan tipe Frequency Modulated Continuos Wave (FMCW) yang beroperasi pada frekuensi $24,1 \mathrm{GHz}$ dan daya puncak $50 \mathrm{~mW}$. MRR cukup baik dalam mengamati struktur vertikal RSD namun untuk hujan berintensitas besar yang dikenal dengan hujan konvektif, MRR mengalami atenuasi yang kuat (Chen dkk., 2016). Dengan demikian, RSD dari MRR untuk hujan konvektif kurang akurat. Karena atenuasi gelombang elektromagnet sebanding dengan intensitas curah hujan, maka untuk hujan dengan intensitas rendah $(\mathrm{R}<10$ $\mathrm{mm} / \mathrm{jam}$ ) tingkat atenuasi rendah sehingga pengaruhnya terhadap RSD yang dihasilkan juga kecil. Oleh karena itu, MRR dapat memberikan informasi yang cukup akurat untuk struktur vertikal RSD bagi hujan dengan intensitas ringan yang dikenal dengan hujan stratiform.

Penelitian ini meneliti tentang distribusi arah vertikal RSD hujan stratiform di Kototabang (0,200 LS; $100,32^{\circ} \mathrm{BT} ; 865 \mathrm{~m}$ di atas permukaan laut) dengan menggunakan MRR. Penelitian struktur vertikal RSD di Kototabang telah dilakukan oleh (Kozu dkk., 2005; Kozu dkk., 2006; Marzuki dkk., 2010; Marzuki dkk., 2013a; Marzuki dkk., 2013b; Vonnisa dkk., 2014; Rahayu dkk., 2016). Sebagian besar penelitian fokus pada karakteristik RSD di permukaan tanah. Untuk struktur vertikal RSD, terdapat beberapa penelitian seperti Kozu dkk. (2005) yang menggunakan Equatorial Atmospheric Radar (EAR), Vonnisa dkk. (2014) menggunakan EAR dan Bondary Layer Radar (BLR), dan Rahayu dkk. (2016) menggunakan MRR. Penelitian Rahayu dkk. (2016) lebih difokuskan untuk menguji kinerja MRR di Kototabang dengan membandingkan RSD dari MRR dengan Particel Size Velocity (Parsivel) dan Optical Rain Gauge (ORG). Penelitian tersebut tidak melakukan analisa struktur vertikal RSD dengan detil. Proses mikrofisika yang dominan dialami oleh butiran hujan di Kototabang juga belum diteliti. Oleh karena itu, dalam penelitian ini diteliti distribusi arah vertikal RSD dari hujan stratiform untuk mengetahui proses mikrofisika yang dialami oleh butiran hujan. Selain itu, penelitian ini juga akan melihat perubahan hubungan $Z-R$ terhadap penurunan ketinggian.

\section{METODE}

MRR adalah radar yang bekerja secara vertikal dan menyediakan parameter hujan menggunakan prinsip Doppler (Peters dkk., 2002). Parameter yang diperlukan seperti RSD, diameter butiran $(D)$, intensitas curah hujan $(R)$, reflektifitas $(Z)$, dan kandungan uap air $(L W C)$ diambil menggunakan fungsi grep yang ada pada software Cygwin. Untuk mendapatkan parameter hujan stratiform dilakukan filter menggunakan software Matlab dengan menghitung selisih parameter $Z$ pada ketinggian 4,05 $\mathrm{km}$ dan 3,45 km lebih besar dari 4,2 dBZ. Selain itu nilai $R$ pada ketinggian $150 \mathrm{~m}$ dan $300 \mathrm{~m}$ harus lebih besar dari 0 untuk memastikan data tersebut merupakan data saat hujan. RSD untuk hujan stratiform dikelompokkan menjadi 4 kelas intensitas yang mengacu pada Tokay dan Short (1996). Hal ini untuk memberikan informasi awal tentang perbedaan RSD untuk setiap ketinggian di Kototabang. Untuk melihat karakteristik RSD lebih lanjut dimodelkan dengan distribusi gamma sebagai berikut :

$$
\mathrm{N}(\mathrm{D})=\mathrm{N}_{\mathrm{T}} \frac{\Lambda^{m+1} D^{m}}{\Gamma(m+1)} \exp (-\Lambda D)
$$

dimana $N(D)$ merupakan fungsi $\mathrm{RSD}\left(\mathrm{mm}^{-1} \mathrm{~m}^{-3}\right), N_{T}$ adalah parameter intercept dengan satuan $\mathrm{m}^{-3}, m$ adalah parameter bentuk (shape) dan $\Lambda$ merupakan parameter slope dari distribusi gamma dengan satuan $\mathrm{mm}^{-1}$. Parameter gamma $\left(m, N_{T}\right.$, dan $\Lambda$ ) dihitung menggunakan metode momen. Metode momen dikembangkan berdasarkan prinsip bahwa semua parameter hujan merupakan fungsi RSD yang secara umum dapat ditulis (Kozu dan Nakamura, 1991): 


$$
\mathrm{M}_{\mathrm{i}}=\int_{0}^{\infty} \mathrm{N}(\mathrm{D}) \mathrm{D}^{\mathrm{i}} d D
$$

dimana $M_{i}$ merupakan momen RSD. Dalam penelitian ini digunakan momen ke-3, 4 dan 6 karena tiga momen ini mendekati kepada parameter fisis hujan yaitu $M_{3} \cong L W C, M_{4} \cong R$ dan $M_{6}$ $\cong Z$.

Perhitungan dilakukan untuk semua ketinggian sehingga dapat diamati perubahan parameter terhadap perubahan ketinggian. Perubahan parameter terhadap ketinggian diamati dengan membuat grafik parameter untuk setiap intensitas curah hujan. Tahap akhir yang dilakukan adalah menghitung persamaan $Z-R$. Persamaan $Z-R$ menggunakan Least Squares Regression (LSR) dalam skala log, kemudian diplot dalam bentuk grafik hubungan koefisien $A$ dan $b$ terhadap ketinggian yang terlebih dahulu dikoreksi dengan metode Sequential Intensity Filtering Technique (SIFT) untuk mengurangi keacakan data.

\section{HASIL DAN DISKUSI}

\subsection{RSD Rata-Rata}

Gambar 1 memperlihatkan $R S D$ rata-rata dari hujan stratiform di Kototabang untuk 4 kelas intensitas curah hujan, dimulai dari hujan sangat ringan $(0,1 \leq R \leq 1 \mathrm{~mm} / \mathrm{h})$ sampai dengan hujan lebat $(5 \leq R \leq 10 \mathrm{~mm} / \mathrm{h})$. Pengelompokan ini mengacu pada pembagian intensitas hujan oleh Tokay dan Short (1996). Pada ketinggian 3,4 km sampai dengan 3,9 km di atas permukaan tanah, jumlah butiran hujan mengalami peningkatan yang sangat signifikan terutama pada butiran berdiameter kecil. Atmosfer pada ketinggian ini diperkirakan merupakan daerah melting layer dimana partikel es mulai mencair menjadi butiran hujan. Melting layer merupakan indikasi bahwa jenis hujan tersebut merupakan hujan stratiform. Pada hujan stratiform berintensitas rendah, butiran yang sampai ke permukaan tanah memiliki diameter butiran yang lebih kecil dibandingkan butiran dari hujan stratiform berintensitas lebih tinggi. Untuk intensitas hujan sangat ringan (Gambar 1a), butiran yang paling besar teramati adalah berdiameter 2,2 $\mathrm{mm}$, sedangkan untuk hujan lebat (Gambar 1d) butiran terbesar berdiamer kurang dari 3,3 mm.
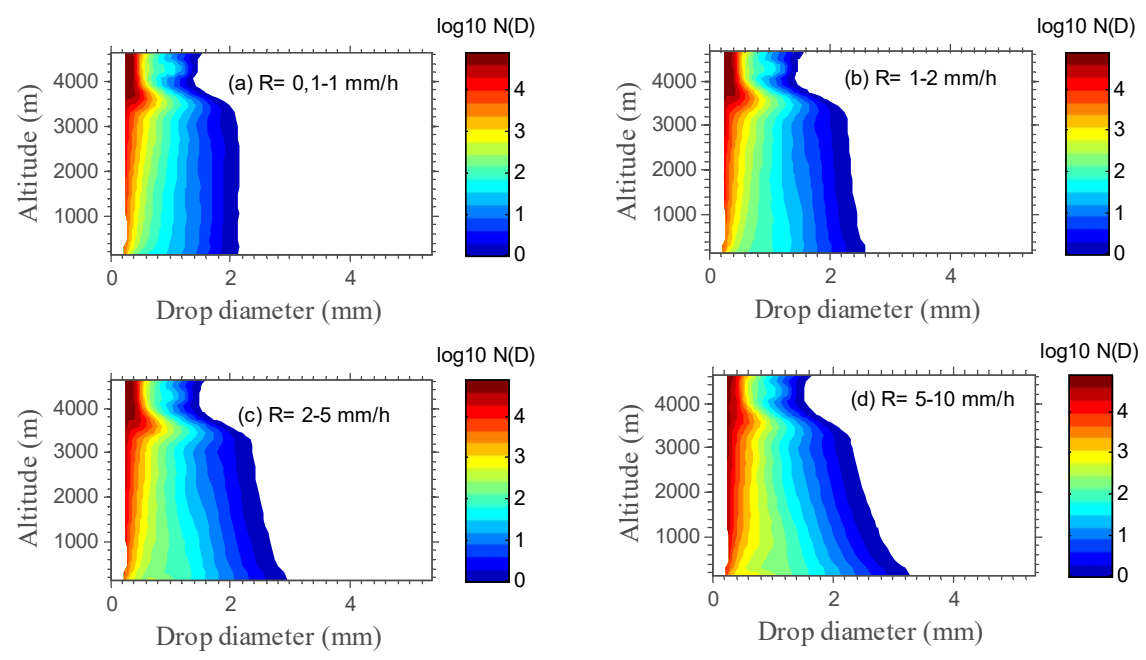

Gambar 1 Profil rata-rata RSD hujan stratiform untuk 4 kelas intensitas curah hujan (a) sangat ringan (b) ringan (c) sedang dan (d) lebat

\subsection{Profil Rata-Rata Parameter Hujan}

Parameter hujan seperti rainfall rate $(R)$, radar reflectivity $(Z)$, Liquid Water Content $(L W C)$ dan kecepatan jatuh butiran $(v)$ merupakan fungsi RSD. Oleh karena itu karakteristik profil arah vertikal RSD yang digambarkan pada Gambar 1 akan terlihat juga pada distribusi vertikal dari $R, Z, L W C$ dan $v$ pada Gambar 2 . 
Profil rata-rata dari $R, Z, L W C$, dan $v$ (Gambar 2a-d) untuk 4 jenis intensitas curah hujan stratiform menunjukkan pola hampir sama pada ketinggian di atas lapisan melting layer, namun berbeda untuk ketinggian di bawah melting layer. Pada lapisan melting layer terjadi pembalikan kemiringan untuk profil $R, Z$ dan $L W C$ (Gambar 2a-c) yang awalnya memiliki kemiringan positif menjadi kemiringan negatif. Pembalikan gradien parameter pada melting layer yang dikenal sebagai Bright Band (BB) tersebut menggambarkan perubahan fase butiran dari es menjadi cair. Ketinggian melting layer dapat ditentukan oleh perubahan signifikan dari kecepatan jatuh butiran hujan (Gambar 2d) yaitu pada ketinggian 3,4-3,9 km. Pada lapisan di bawah melting layer, dimulai pada ketinggian sekitar $3,3 \mathrm{~km}$, nilai $R, Z$ dan $L W C$ pada setiap kelas intensitas curah hujan memiliki nilai yang berbeda. Semakin tinggi intensitas curah hujan semakin besar peningkatan parameter tersebut dengan penurunan ketinggian. Kemiringan dari grafik hubungan parameter tersebut hampir sama untuk semua intensitas curah hujan selain hujan dengan intensitas lebat. Hujan stratiform dengan intensitas lebat ini walaupun memiliki melting layer namun merupakan transisi antara hujan stratiform dan konvektif (Atlas dkk., 1999). Hal ini konsisten dengan peningkatan RSD dengan penurunan ketiggian (Gambar 1).
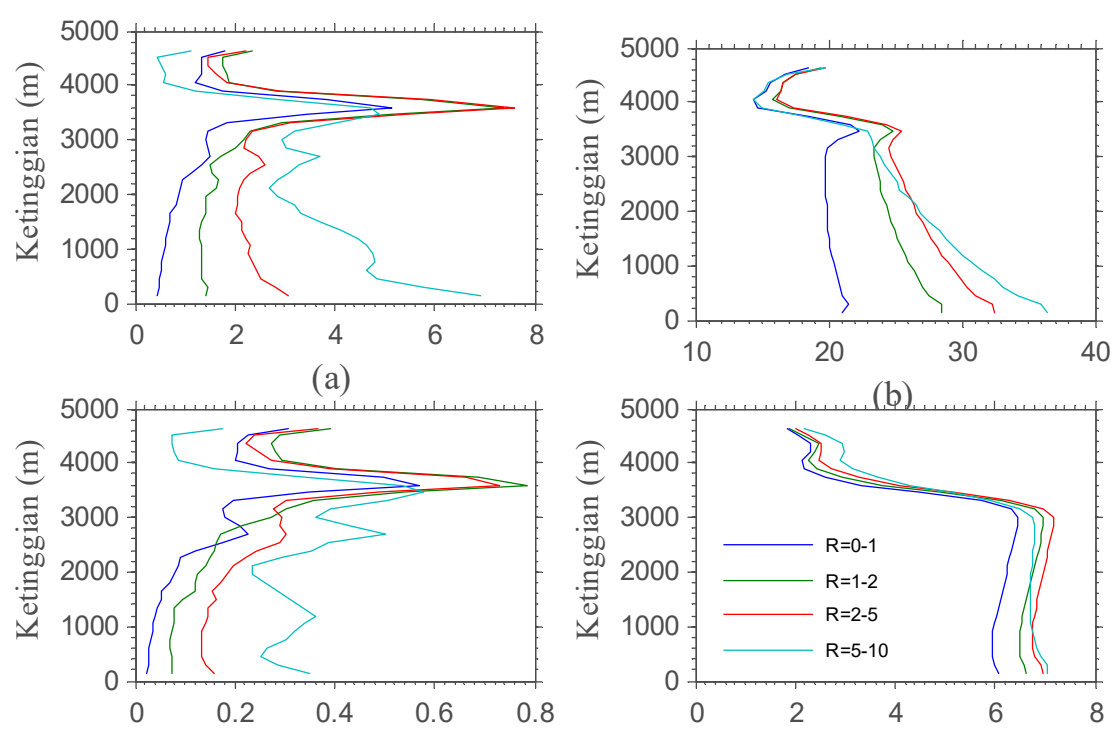

(c)

(d)

Gambar 2 Perbandingan parameter hujan stratiform terhadap ketinggian untuk 4 kelas intensitas hujan (a) rainfall rate $(\mathrm{mm} / \mathrm{h})(\mathrm{b})$ radar reflectivity $(\mathrm{dBZ})$ (c) liquid water content $(\mathrm{g} / \mathrm{m} 3)$ dan $(\mathrm{d})$ falling velocity $(\mathrm{m} / \mathrm{s})$

Parameter hujan yang merupakan fungsi RSD akan memberikan informasi proses fisis yang dialami butiran hujan. Nilai $Z$ sangat dipengaruhi oleh konsentrasi ukuran butiran dimana semakin banyak konsentrasi butiran berukuran besar maka akan semakin besar nilai $Z$, karena $Z$ sebanding dengan $D^{6}$. Pada hujan stratiform dengan intensitas tinggi kemiringan positif pada nilai $Z$ menunjukkan adanya peningkatan konsentrasi butiran besar yang disebabkan oleh proses penggabungan (coalescence) butiran-butiran berukuran kecil akibat adanya updraft. Hal ini dapat terlihat dari berkurangnya jumlah konsentarsi butiran berukuran kecil dan meningkatnya jumlah konsentrasi butiran berukuran besar.

\subsection{Parameter RSD}

Untuk melihat karakteristik RSD hujan stratiform maka digunakan parameter gamma dari data yang terekam setiap menit. Gambar 3 memperlihatkan parameter gamma rata-rata dari RSD yang dihitung menggunakan metode momen. Parameter gamma ini digambarkan dengan grafik rata-rata shape parameter $(m)$, slope $(\Lambda), N_{T}$ dan mass-weight mean diameter $\left(D_{m}\right)$ terhadap ketinggian. Parameter gamma rata-rata dari RSD ini dapat digunakan untuk menjelaskan proses fisika yang terjadi pada butiran. Dari parameter gamma tersebut terlihat bahwa proses yang terjadi pada butiran hujan di atas dan di bawah melting layer untuk hujan 
stratiform berbeda. Hal ini ditandai dengan perbedaan kemiringan grafik parameter gamma terhadap ketinggian, terutama pada shape parameter $(m)$.

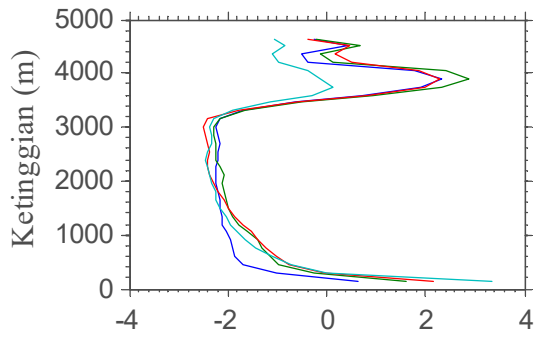

(a)

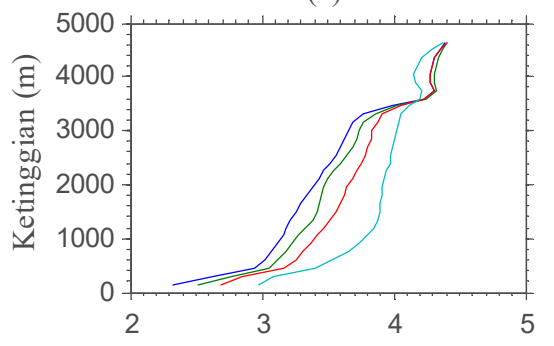

(c)

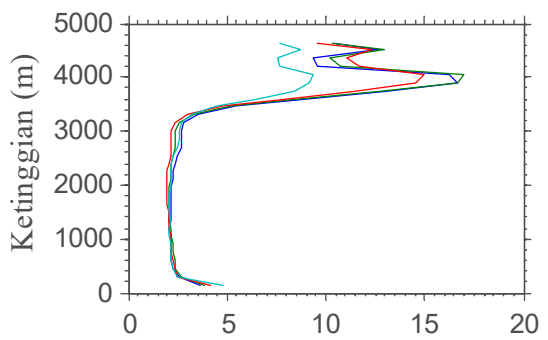

(b)

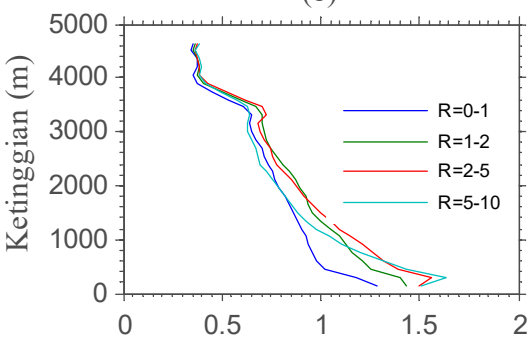

(d)

Gambar 3 Perbandingan rata-rata parameter gamma hujan stratiform untuk 4 kelas intensitas curah hujan (a) shape parameter $(m)$ (b) slope $(\Lambda)$ (c) total raindrop consentration $\left(N_{T}\right)$ dan

(d) Mass weight mean diameter $\left(D_{m}\right)$

Secara umum dapat dilihat bahwa nilai shape parameter $(m)$ di bawah melting layer mulai ketinggian 3,3 km meningkat dengan penurunan ketinggian yang menandai penurunan konsentrasi butiran kecil. Hal ini konsisten dengan distribusi vertikal $D_{m}$. Pengurangan jumlah butiran kecil ini kemungkinan disebabkan oleh proses evaporasi dan updraft sehingga butiran kecil tidak sampai ke permukaan karena menguap atau tidak bisa melawan gaya vertikal ke atas oleh proses updraft. Selain itu, penurunan jumlah butiran kecil ini juga dapat disebabkan oleh proses penggabungan (coalescence). Walaupun terjadi peningkatan butiran hujan yang besar melalui coalescence tetapi penurunan jumlah butiran hujan yang kecil lebih dominan sehingga berdampak pada penurunan nilai $N_{T}$ terhadap ketinggian (Gambar 3c). Pada lapisan di atas 3,3 $\mathrm{km}$ parameter gamma memiliki kecenderungan tidak beraturan sehingga sangat sulit untuk menentukan proses fisika yang terjadi pada lapisan ini. Hal ini kemungkinan disebabkan karena pada ketinggian di atas 3,3 $\mathrm{km}$ butiran hujan masih bercampur dengan butiran es.

\subsection{Persamaan Z-R}

Salah satu aplikasi penting dari data RSD adalah untuk membentuk persamaan $Z-R\left(Z=A R^{b}\right)$. Persamaan ini selain digunakan untuk mengonversi nilai $Z$ dari radar meteorologi menjadi intensitas curah hujan $(R)$ juga dapat digunakan untuk melihat proses fisis yang terjadi pada butiran hujan.

Nilai dari koefisien Z-R untuk setiap ketinggian dapat dilihat pada Gambar 4. Nilai dari koefisien $A$ dan $b$ berubah terhadap ketinggian. Nilai $A$ semakin besar terhadap penurunan ketinggian sedangkan nilai $b$ semakin kecil terhadap penurunan ketinggian. Bentuk profil ini sama dengan tipikal nilai $A$ dan $b$ untuk hujan stratiform (Cifelli dkk., 2000). Pada lapisan melting layer nilai $A$ sangat kecil (rata-rata sebesar 14,67) dan nilai $b$ sangat besar (rata-rata sebesar 1,6). Persamaan $Z-R$ pada lapisan melting ini merupakan persamaan $Z-R$ untuk partikel air padat seperti kristal es. Pada ketinggian di bawah melting layer $(3,3 \mathrm{~km}$ hingga $0,45 \mathrm{~km})$, nilai $A$ meningkat dengan penurunan ketinggian sedangkan nilai $b$ berkurang. Nilai $A$ pada ketinggian 3,3 km adalah 95 meningkat menjadi 331 pada ketinggian dekat permukaan tanah $(0,45 \mathrm{~km})$. Dengan demikian, koefisien $A$ dan $b$ tidak konstan untuk setiap ketinggian, sehingga penggunaan hubungan Marshall-Palmer (MP) yaitu $Z=200 R^{1,6}$ untuk setiap ketinggian pada radar cuaca dapat mempengaruhi akurasi pengamatan radar cuaca. 

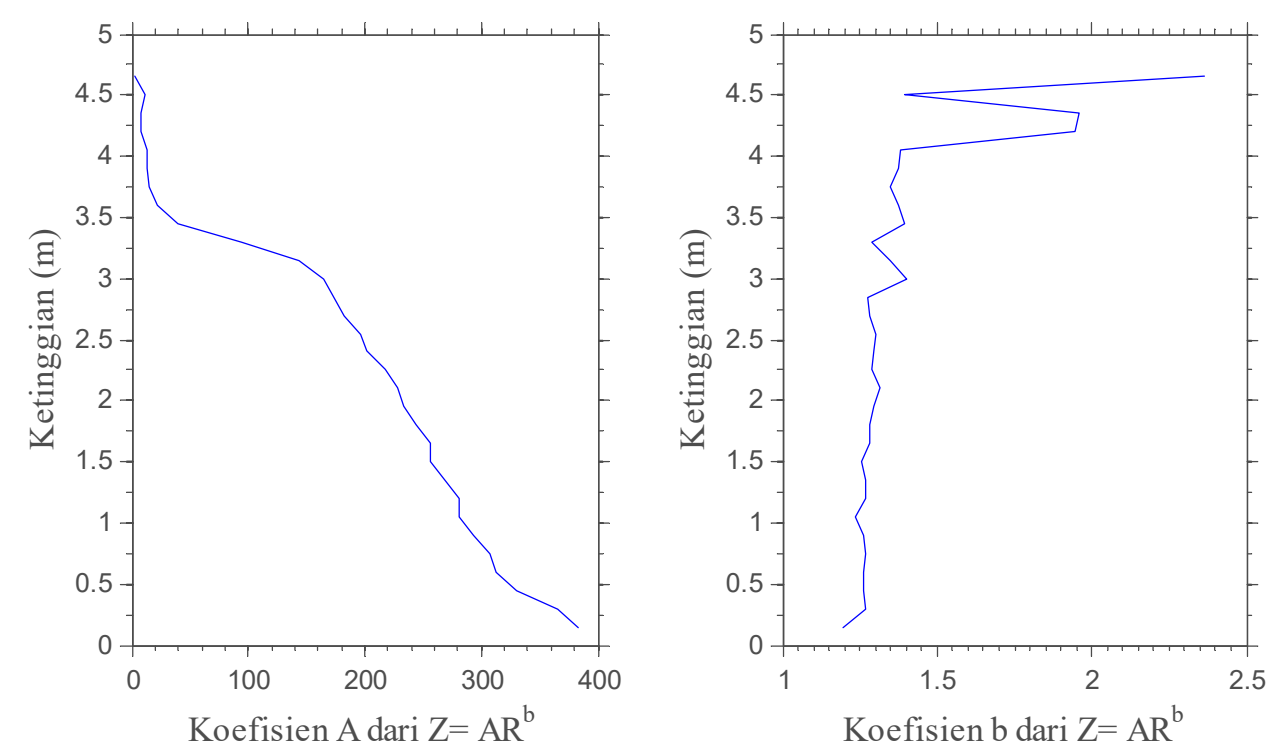

Gambar 4 Koefisien dari persamaan $\mathrm{Z}=\mathrm{AR}^{\mathrm{b}}$ dari hujan stratiform di Kototabang

Nilai $A$ pada ketinggian $0,45 \mathrm{~km}$ di atas permukaan tanah lebih besar dari nilai $A$ yang didapatkan oleh Marzuki dkk. (2013b) menggunakan disdrometer. Hal ini disebabkan karena penelitian tersebut menghitung untuk seluruh jenis hujan, sedangkan penelitian ini hanya menghitung RSD untuk hujan stratiform saja. Pada lapisan atmosfir dimana hujan terjadi $(3,3$ $\mathrm{km}-0,45 \mathrm{~km}$ ), perubahan nilai $A$ dan $b$ terhadap ketinggian cukup seragam yang mengindikasikan tidak begitu aktifnya pertumbuhan butiran hujan pada hujan stratiform. Perubahan nilai $A$ dan $b$ terhadap ketinggian dapat menjadi indikasi proses fisika yang dialami oleh butiran hujan. Nilai $A$ bertambah terhadap penurunan ketinggian dan nilai $b$ berkurang terhadap ketinggian maka proses mikrofisika yang terjadi adalah proses evaporasi (Wilson dan Brandes, 1979). Proses kinematika yang bekerja adalah proses size shorting dan untuk gaya vertikal yang bekerja adalah updraft yang dapat mendorong terjadinya penggabungan (coalescence). Namun, pada hujan stratiform proses size shorting tidak signifikan (Cifelli dkk., 2000). Hal ini menunjukkan bahwa untuk hujan stratiform di Kototabang butiran yang sampai ke permukaan mengalami proses evaporasi, sehingga jumlah butiran hujan berukuran kecil yang sampai kepermukaan lebih kecil dari saat mulai jatuh. Evaporasi yang terjadi disebabkan oleh tingginya temperatur atmosfer, terutama pada siang hari (Mahr dan Micheal, 1983). Selain itu, butiran hujan mengalami proses coalescence yang cukup kuat yang ditandai dengan peningkatan nilai $D_{m}$ (Gambar 4). Coalescence ini didukung oleh updraft yang ditimbulkan oleh turbulence yang terjadi di Kototabang. Adanya proses evaporasi dan coalescence ini menyebakan jumlah butiran hujan menurun terhadap ketinggian yang ditandai dengan berkurangnya nilai $N_{T}($ Gambar 3c).

\section{KESIMPULAN}

Distribusi vertikal butiran hujan stratiform di Kototabang memperlihatkan adanya pertumbuhan yang cukup signifikan. Pertumbuhan RSD hujan stratiform pada ketinggian 3,9$3,4 \mathrm{~km}$ teramati untuk semua ukuran butiran, yang menandakan ketinggian daerah melting layer di Kototabang. Hal ini juga terlihat dari hubungan parameter hujan terhadap ketinggian pada lapisan tersebut. Di bawah daerah melting layer terjadi penurunan konsentrasi butiran berukuran kecil dan peningkatan konsentrasi butiran besar. Hal ini diperkirakan disebabkan oleh proses evaporasi dan updraft pada butiran kecil. Selain itu, proses penggabungan butiran (coalescence) terjadi pada hujan stratiform dengan intensitas tinggi. Peningkatan konsentrasi butiran berukuran besar terlihat dengan jelas dari gradien $Z$ yang bernilai positif. Hal ini juga ditandai dengan perubahan parameter RSD dan koefisien persamaan Z-R terhadap penurunan ketinggian. Dengan demikian, asumsi butiran hujan stratiform yang konstan pada radar meteorologi selama ini tidak begitu tepat untuk kawasan tropis, terutama di Kototabang. 


\section{UCAPAN TERIMA KASIH}

Terima kasih kepada Dr. Toyoshi Shimomai dari Universitas Shimane yang telah mengoperasikan MRR dan kepada Prof. Hiroyuki Hashiguchi dari Universitas Kyoto dan Lembaga Penerbangan dan Antariksa Nasional (LAPAN) Kototabang yang telah menyediahkan data MRR yang digunakan dalam penelitian ini. Penelitian ini didanai oleh Hibah Riset Dasar Kemenristekdikti dengan nomor kontrak T/3/UN.16.17/PT.01.03/PD-Kebencanaan/2019.

\section{DAFTAR PUSTAKA}

Atlas, D., Ulbrich, D. W., Marks, F. D. Jr., Amitai, E. dan Williams, C. R., 1999, Dopler Radar Characteristics of Precipitation at Vertical Incidence, Journal of Geophysical Research, Vol. 104, Hal. 6155-6169.

Chen, Y., An, J. L., Lui, H. Z. dan Duan, J., 2016, An Observational on Vertical Raindrop Size Distribution During Stratiform Rain in Semiarid Plateu Climate Zone, Atmospheric and Oceanic Science Letter, Vol. 9, Hal. 178-184.

Cifelli, R., Williams, C. R., Rajopadhyaya, D. K., Avery, S. K., Gage, K. S. dan May ,P.T., 2000, Drop-Size Distribution Characteristics in Tropical Mesoscale Convective Systems, Journal Applied Meteorology, Vol. 39, Hal. 760-777.

Coppens, D. dan Haddad, Z.S., 2000, Effect of Raindrop Size Distribution Variationson Microwave Brightness Temperature Calculation, Journal of Geophysical Research, Vol. 105, No. 19, hal. 483-489.

Currier, P. E., Avery, S. K., Balsley, B. B. dan Gage, K. S., 1992, Combined use of $50 \mathrm{Mhz}$ and 915 Mhz Wind Profilers in the Estimation of Raindrop Size Distribution, Geophysical Research Letter, Vol. 19, Hal. 1017-1020.

Kozu, T. dan Nakamura, K., 1991, Rainfall Parameter Estimation from DualRadar Measurements Combining Reflectivity Profile and Path-Integrated Attenuation, Journal of Atmospheric and Oceanic Technology, Vol. 8, Hal. 259-271.

Kozu, T., Shimomai, T., Akramin, Z., Marzuki, M., Shibagaki, Y. dan Hashiguchi, H., 2005, Intraseasonal Variation of Raindrop Size Distribution at Koto Tabang, West Sumatra, Indonesia, Geophysical Research Letter, Vol. 32, Hal. 1-4.

Mahrt, L. dan Micheal, E., 1983, The Influence of Atmospheric Stability on Potential Evaporation, Journal of Climate and Applied Meteorology, Vol. 23, Hal. 222-234.

Marzuki, M., Hashiguchi, H., Yamamoto, M. K., Mori, S. Dan Yamanaka, M. D., 2013a, Regional Variability of Raindrop Size Distribution over Indonesia, Journal of Annales Geophysicae, Vol. 31, Hal. 1941-1948.

Marzuki, M., Kozu, T., Shimomai, T., Hashiguchi, H., Randeu, W. I., dan Vonnisa, M., 2010, Raindrop Size Distribution of Convective Rain over Equatorial Indonesia During the First CPEA Campaign, Journal of Atmospheric Research, Vol. 96, Hal. 645-655.

Marzuki, M., Kozu, T., Shimomai, T., Randeu, W. I., Hashiguchi, H. dan Shibagaki, Y., 2009, Diurnal Variation of Rain Attenuation Obtained from Measurement of Raindrop Size Distribution in Equatorial Indonesia, IEEE Transaction on Antennas and Propagation, Vol. 57, Hal. 1191-1196.

Marzuki, Randeu, W. I., M., Kozu, T., Hashiguchi, H. dan Schonhuber, M., 2013b, Raindrop Axis Ratio, Fall Velocities and Size Distribution over Sumatra from 2D - Video Disdrometer Measurement, Journal of Atmospheric Research, Vol. 119, Hal. 23-37.

Paters, G., Fischer, B. dan Anderson, T., 2002, Rain observations with avertically looking Micro Rain Radar (MRR), Journal of Boreal Environtment, Vol. 7, Hal. 353-362.

Rahayu, I., Marzuki, M., Hashiguchi, H. dan Shimomai, T., 2016, Struktur Vertikal Distribusi Butiran Hujan di Kototabang Berdasarkan Pengamatan Micro Rain Radar (MRR), Jurnal Fisika Unand, Vol. 5, Hal. 287-296.

Tokay, A. dan Short, D. A., 1996, Evidence from Tropical Raindrop Spectra of the Origin of Rain from Statiform Versus Convective Clouds, Journal Applied Meteorology, Vol. 35, Hal. 355-371. 
Vonnisa, M., Kozu, T. dan Shimomai, T., 2014, Pengembangan Metode DualFrekuensi untuk Mengamati Struktur Vertikal Raindrop Size Distribution (DSD) di Kototabang, Jurnal Ilmu Fisika, Vol. 6, Hal. 52-58.

Wilson, J. W. dan Brandes, E. A., 1979, Radar Measurement of Rainsfall - A Summary, Journal of American Meteorology Society, Vol. 60, Hal. 1048-1060. 